\title{
INCLUSIVE DIGNITY AND LAND REFORM IN SOUTH AFRICA
}

\author{
Nico Koopman \\ Systematic Theology \& Ecclesiology \\ Stellenbosch University
}

\begin{abstract}
This article explores the light that the notion of inclusive dignity might shed on the quest for land reform and land restitution in South Africa. It offers a discussion of the notion of inclusivity by outlining the various faces of exclusivity in contemporary societies, especially on the continent of Africa. It discusses the indispensable role of three dimensions of human rights to acknowledge, affirm and actualize dignity for all, including nature. It argues that dignity can be actualized in two ways, namely through the provision of opportunities for people whose land had been take away, to build a life where the features of dignity are actualized. This implies access to the most basic necessities and goods of life, participation in the political and economic processes of society, and opportunities to develop God-given potentialities. A second mode of actualizing dignity in the context of land restitution processes is that people who choose to return to the original or an equivalent piece of land, be granted the opportunity to return, and that they receive appropriate support from government and other institutions to use the land optimally.
\end{abstract}

Key Words: Inclusive Dignity; Human Rights; Land Reform; Restitution; Healing Justice

\section{Introduction}

Awakening on Friday morning, June 20, 2013, the South African Native found himself, not actually a slave, but a pariah in the land of his birth (Sol Plaatje, quoted by Max du Preez. ${ }^{1}$

The South African journalist and public intellectual, Max du Preez, ${ }^{2}$ describes the centrality of the challenge of land reform in a very clear way:

No national issue elicits as much anger, fear and fiery confrontation as the ownership of land. At the same time, few, if any, other national issues are as misunderstood, misrepresented and mismanaged as the land question.

These two sets of remarks of Du Preez about the emotive character of the land reform issue, and about misunderstandings thereof, will be considered in the discussions of land reform in this article.

This contribution discusses the quest for a life of dignity in which all people and the rest of creation are included, as ethical parameter for land reform in South Africa. The notion of

M du Preez, A rumour of spring. South Africa after 20 years of democracy. Cape Town: Zebra Press, 2014:159.

2 M du Preez, A rumour of spring, p.159. 
inclusive dignity is investigated first. Thereafter the meaning of and implications of this notion for the land reform process in South Africa are discussed. ${ }^{3}$

\section{Inclusive Dignity as Ethical Parameter}

Billions of people all over the world experience socio-economic exclusion. This happens globally in both so-called developing and developed countries. This exclusion occurs with and on the continent of Africa more than on any other, and this phenomenon is present in post-apartheid South Africa as well.

Stéphane Hessel and Edgar Morin ${ }^{4}$ describe the global dimensions of exclusion and inequality. They state that globalisation carries within it both the best and the worst that can come from human beings. At best globalisation paves the way for acknowledging, as never before, our global interdependence, and our common fate, and it creates the possibility of a global homeland without negating the idea of individual homelands. At worst globalisation manifests itself as the uncontrolled, manipulative and destructive power of science and technology, a global economy of which the highest goal is the maximalisation of profit, the proliferation of weapons of mass destruction and the destruction of the biosphere, and especially in the early days of the $21^{\text {st }}$ century the tyranny of financial capitalism which knows no boundaries and which subjects countries and nations to its speculations, the return of xenophobia as well as racial, ethnic and territorial exclusion.

They ${ }^{5}$ argue that protests of the Arab Spring, and protests in Spain and Greece, Israel and Chili, London and India (and might I add, South African mines and farms and cities and towns) have this common agenda: increasing inequality, the shameless cynicism of corruption, and continuous unemployment.

Jürgen Moltmann describes continents like Africa as the contexts of sub-modernity those who are excluded from the positive fruit of ambivalent modern political and socioeconomic arrangements. $\mathrm{He}^{6}$ employs the notion of sub-modernity to describe this exclusion of Africans.

Millions of illiterate, semi-schooled and inappropriately schooled Africans discover that they are redundant in a globalised economy that demands knowledge and skills for a socalled tertiary economy of information and communication technology and a variety of highly sophisticated services. Those who were required for agricultural and manufacturing economies are needed less by the new economy. Moltmann explains: "More and more countries in Africa and Latin America are ceasing to be of any interest at all to the industrial West. The number of people and markets that are no longer needed is steadily increasing. The exploited Third World is being turned into a superfluous backwoods, and its population into "surplus people'."7

Some scholars describe Africa as the Fourth World, because it is the continent that experiences the highest level of socio-economic exclusion. They reckon that Africa is the

This contribution draws upon and extends my ongoing research on themes such as inclusivity, human dignity and human rights.

$4 \quad$ S Hessel and E Morin, De weg van de hoop - (translated from the original 2011 French version: Le chemin de l'espérance. Amsterdam: Van Gennep, 2011:11.

5 S Hessel and E Morin, De weg van de hoop, p.15.

6 J Moltmann, God for a secular society. The public relevance of theology. Minneapolis: Fortress Press, 1999:11-12.

7 J Moltmann, God for a secular society, p.13. 
only continent where poverty is not on the decrease, but where it is actually growing. On no continent do we witness the violation of dignity as on the continent of Africa.

South African public intellectual, and former senior official of the World Bank, Mamphela Ramphele, ${ }^{8}$ describes the growing levels of socio-economic exclusion as one of the major public challenges for contemporary South Africa. Despite the transition to democracy twenty years ago, and the positive political and macro-economic changes, millions of South Africans are still excluded from the basic necessities and goods of life, and from the opportunity to participate in building a new society. In fact, for many the current situation is more desperate than during apartheid. The levels of inequality in South Africa have increased. South Africa now has the highest Gini-coefficient in the world. And although white people still enjoy more socio-economic privileges the gap between rich and poor does not run along colour lines exclusively any longer.

The challenge of socio-economic exclusion constitutes a human dignity and human rights challenge. Where people experience exclusion from the goods of life, especially socio-economic exclusion, their human dignity is not fully acknowledged, affirmed and actualised.

Dutch social scholar Rob Buitenweg ${ }^{9}$ argues that human dignity is not fulfilled where people still experience exclusion from three sets of goods: Firstly, against the background of the vulnerability of humans we embark on the quest for wellbeing, i.e. the quest to protect ourselves against suffering and the threats to our physical existence. We therefore strive for the most basic goods for human life, such as food, clothes, housing and medical care.

Secondly, humans are also social, relational beings. We are dependent upon each other. We care for each other. Our membership of communities establishes our identities; therefore we engage in the quest to participate in various social processes. We oppose isolation, alienation and exclusion. We strive to participate in communal processes, especially those that give form and content to our living together. Isolation and exclusion violate our self-respect.

Thirdly, humans are open and not pre-determined and programmed beings. Neither are we determined by our instincts. We can make choices, and we cannot avoid making choices. We are responsible beings. This inherent quality of openness prompts us to strive for freedom. We do not want to be imprisoned, trapped, enslaved, forced and oppressed. We hunger for spaces in which we can make choices and live authentically according to our own preferences.

So, where our physical needs are not met, where we are denied the opportunity of participation and contribution to life, and where we do not experience freedom and responsibility, our dignity is violated.

In his reflections on human dignity Wolfgang Huber emphasises that we can come to good definitions of human dignity only if we ask the question about the things from which people are excluded. $\mathrm{He}^{10}$ makes helpful remarks about the definition of human dignity: "The concept of human dignity is among the most controversial in the language of ethics

M Ramphele, Conversations with my sons and daughters. Johannesburg: Penguin Books, 2012.

9 R Buitenweg, Recht op een menswaardig bestaan. Een humanistieke reflectie op social-economische mensenrechten. Utrecht: Uitgeverij de Graaff, 2001:94-95.

10 W Huber, Violence. The unrelenting assault on human dignity. Minneapolis: Fortress Press, 1996:10. (Translated by Ruth Gritsch from German, Die tägliche Gewalt: Gegen den Ausverkauf der Menschenwürde (Freiburg im Breisgau: Verlag Herder, 1993). 
and politics. Yet those whose dignity has been disregarded or even trampled know full well what human dignity means. Its meaning is established by the denial of it."

In the same vein Nigerian scholar, Wole Soyinka, ${ }^{11}$ describes the violation of dignity on the African continent with words such as anti-humanism, ${ }^{12}$ reduction in self-esteem, ${ }^{13}$ nullification of human status, ${ }^{14}$ humiliation, ${ }^{15}$ assault on dignity. ${ }^{16}$

Human dignity has two building blocks, namely justice and freedom. Dignity is violated where people are excluded from the compassionate justice for which John Calvin pleaded, and from the twofold freedom from oppression and enslavement, and freedom for service to God and others as which Luther had advanced.

The actualisation of dignity is served by the quest to implement and fulfill human rights. Jürgen Habermas ${ }^{17}$ makes a strong case for the actualisation of dignity through the fulfillment of human rights. He discusses the connection between human dignity and human rights. Habermas ${ }^{18}$ explains that dignity is a notion with roots in the long Christian tradition and in the classic philosophical tradition.

It is, however, remarkable, he ${ }^{19}$ explains, that in the development of human rights during the eighteenth and nineteenth centuries, human dignity did not surface explicitly. The only exception was paragraph 139 of the March 1849 German Constitution, which stated that a free people respect the dignity of even a criminal. The notion of human dignity, however, was crucial in the development of democratic constitutions and bills of rights during the twentieth century in countries such as Germany, Italy and Japan, and one can add to the list, South Africa. This was the case, not because human dignity was added to the bills of rights as an add-on or afterthought, but because the dignity of millions of people was violated in these countries. The Universal Declaration of Human Rights also entrenched dignity as a foundational moral principle against the background of the atrocities of World War Two. Habermas ${ }^{20}$ adds that dignity was in fact implicitly subscribed to in all rights discourses.

Two points are emphasised. Firstly, dignity did not come after human rights. Dignity has a long history. Secondly, dignity provides a moral thrust to human rights discourses. Dignity shows that rights are required where people experience exclusion from justice and freedom. ${ }^{21}$ The moral thrust that dignity provides to human rights discourses paves the way for a twofold involvement in the fulfillment of rights, namely one driven by the conscience of individuals, and the other one driven by the institutional formulation of positive law. ${ }^{22}$ This individual and institutional (constitutional) work for the fulfillment of rights provide to human rights discourse the dimension of a realistic utopia. Rights are no longer

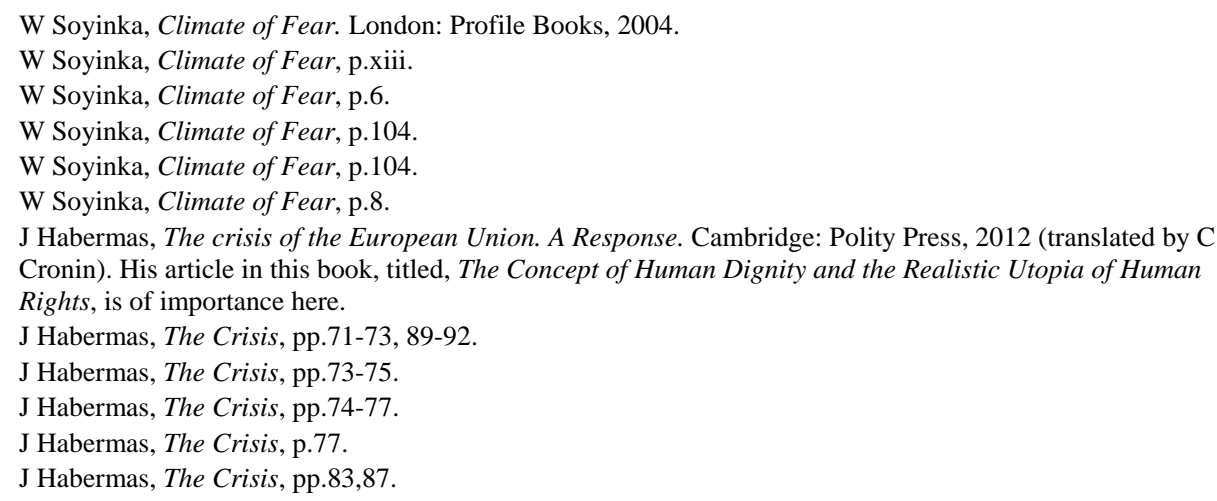


deceptive images of a social utopia which guarantees collective happiness, but are anchored in the institutions of constitutional states themselves. ${ }^{23}$

Habermas also refers to other, related, implications of the basing of human rights in human dignity.

Grounding rights in dignity ensures that we do not talk in abstract terms about rights. Rights need to be spelt out in concrete terms in each particular concrete situation. This orientation to the concrete - specific and particular - paves the way for dialogue and compromise sought in situations where rights are in conflict, and for a commitment to continuous dialogue and co-operation where we deal with incommensurable situations. In specific situations of disagreement and even incommensurability we continue the debate what dignity means in practice. Dignity, therefore, supports human rights discourses and judicial decision-making, especially in pluralistic societies where incommensurability might surface more regularly. ${ }^{24}$

Dignity provides a concreteness to human rights discourses that ensure that the consciousness of suffering individuals ${ }^{25}$ finds its way into the texts of bills of rights and into legal texts. Human dignity helps to exhaust the potential of current rights and to construct new ones. ${ }^{26}$ Like a seismograph it registers what is constitutive for a democratic legal order. ${ }^{27}$

Because human dignity has to do with all dimensions of rights, basing rights in dignity ensures that all types (liberal, participation, social, and cultural) and generations or dimensions (political and civil, socio-economic, developmental and environmental) of rights, receive attention. ${ }^{28}$ Habermas $^{29}$ argues that socio-economic rights should be viewed as of equal value to more classical civil and political rights:

Experiences of exclusion, suffering and discrimination teach us that classical civil rights acquire 'equal value' (Rawls) for all citizens only when they are supplemented by social and cultural rights. The claims to an appropriate share in the prosperity and culture of society as a whole places narrow limits on the scope for shifting systemic costs and risks onto the shoulders of individuals. These claims set constraints on the increase in social inequality and forbid the exclusion of entire groups from social and cultural life as a whole.

Just as it is inadequate to emphasise civil rights at the expense of socio-economic rights it is not sufficient to stress the importance of socio-economic rights only. All rights are interdependent and need to receive joint attention. ${ }^{30}$

Another positive spin-off of basing rights in dignity is the fact that since dignity is universal, all people have equal dignity, ${ }^{31}$ rights have universal significance and

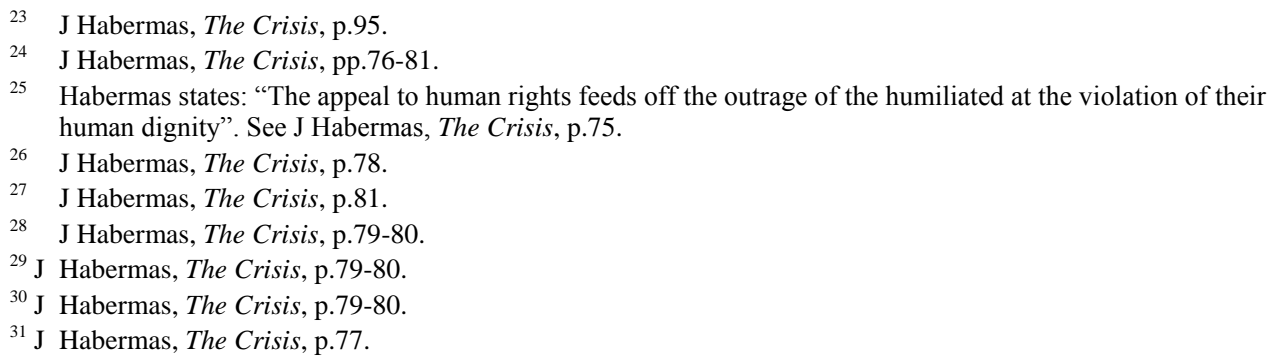


application. Habermas ${ }^{32}$ states: "Human dignity, which is one and the same everywhere and for everyone, grounds the indivisibility of all categories of human rights."

The quest for rights involves the so-called three generations or dimensions of rights, namely political and civil rights, socio-economic rights and rights with regard to development and the natural environment. Especially this so-called third generation rights affirm that human dignity and human rights discourses always takes place in the context of the integrity of creation. The notion of the integrity of creation entails that human life and natural life are integrated and interdependent, and that nature has inherent integrity, worth and value.

So, where people are excluded they do not enjoy dignity, justice or freedom, and their rights are violated.

This article argues that exclusion is overcome where the quest for the actualisation of human dignity through the implementation of human rights is alive. This quest for the actualization of dignity is applied to the challenge of land reform in the next part of this article.

\section{Inclusive Dignity and Land Reform}

In South Africa both the concepts of land restitution and land redistribution are of relevance. Land has been taken away in various illegal and dehumanizing ways from millions of South Africans. The two Land Acts of 1913 and 1936, the Group Areas Act and the Population Registration Act are some of the acts that facilitated this injustice. Consequently land needs to be restituted and redistributed in the light of these severe violations of dignity, injustices and oppression of people. ${ }^{33}$

From the discussion of inclusive dignity in the first part of the article we might infer the following actions in service of land restitution and redistribution.

All people whose land had been taken away should be reconciled with the land. Biblical scholar, Itumeleng Mosala, ${ }^{34}$ decades ago described reconciliation as katalassein, as at-onement, as re-unification with the land. Land stands for the space that brings a life of dignity for all, for humans and nature.

For some landless people this reconciliation with the land means that they do not go back to the original piece of land, but that they do receive the 'land', the space, the opportunities and support to build a life of dignity, i.e. a life where they have access to the necessities of life such as water, food, shelter, health care, education, employment, safe environments, leisure, participation in social, economic, cultural and political life, and the space to actualize their various potentialities and capacities as human beings, potentialities such as freedom, creativity, caring for others, entering into relationships and the taking-up of responsibility. This reconciliation with the land would then imply the actualization of dignity through the implementation and fulfillment of especially the second dimension socio-economic rights and the third dimension ecological rights, as well as the third dimension rights to development.

\footnotetext{
32 J Habermas, The Crisis, p.80.

33 Elsewhere I have discussed the technical and legal aspects regarding land reform in more detail. See $\mathrm{N}$ Koopman, Justice and land reform, in E van der Borght (ed.), The God-given land. Religious perspectives on land reform in South Africa. Amsterdam: Rozenberg Publishers, 2009:104.

34 See I Mosala, The meaning of reconciliation. A Black perspective, in Journal of Theology for Southern Africa, 1987:19-25.
} 
Max du Preez ${ }^{35}$ refers to the statistics that of the 80000 land restitution claims that were received by 1998 , only 5856 claimants preferred land. The majority preferred cash payouts, which amounts to R6 billion. The amount of money spent on land reform since 1994 could have bought $37 \%$ of all commercial farm land, 7 per cent more than the government's yet unmet target. The phenomenon that people prefer to stay in cities and to practice various kinds of professions is the typical tendency of the last few generations in various, especially Western countries in Europe and North America. This phenomenon of the non-preference of becoming farmers co-incides, according to Du Preez, with the phenomenon that a growing percentage of agricultural land is owned and developed not by individuals and families, but by big companies.

So, one could argue that land restitution and land redistribution have to take place mainly through the creation of 'land', of space, of opportunities, of support, for people to build and enjoy a life of dignity, a life where the basic ingredients of a life of dignity are materialized for them. Land restitution and land redistribution also take place where the dignity of the so-called non-human part of creation is also fulfilled through the fulfillment of so-called third dimension ecological rights.

But the story does not end here. There are also people who view above-mentioned general, almost symbolic, form of land restitution and land redistribution as inadequate. Reconciliation with the original piece of land that had been taken away constitutes for them the heart of the actualisation of dignity, and the heart of the fulfillment of their human rights.

In a 1991 speech, ecumenical theologian, Wolfram Kistner, ${ }^{36}$ referred in this regard to the desire of an elderly black man to be reconciled with the land that had been taken away from him:

The land, our purpose in the land, that is what we must achieve. The land is our whole lives, we plough it for food, we build our homes from the soil, we live on it and we are buried in it. When the Whites took our land away from us we lost the dignity of our lives, we could no longer feed our children. We were forced to become servants. We are treated like animals. Our people have many problems, we are beaten and killed by the farmers, the wages we earn are too little to buy even a bag of mealie-meal. We must unite together to help each other and face the Boers. But in everything we do we must remember that there is only one aim and one solution, and that is the land, the soil, our world.

Du Preez ${ }^{37}$ quotes African National Congress leader and public intellectual, Pallo Jordan, who also calls for attention to reconciliation with the original land as the heart of the fulfillment of dignity and liberation:

The emotions around land ... are even more firmly embedded by the various associations with which the land is embellished. We speak of the 'motherland', evocative of the unequivocal love of a mother for her children. 'Mother' is associated with birth, caring and nurturing, all of which inspire warm, positive feelings. Every national movement claims its inspiration is the struggle to reclaim land lost to oppressors or conquerors.

35 M du Preez, A rumour of spring, p.160-161.

36 W Kistner, The need for land-related justice in South Afrika, in A Frochtling and T Maluleke (eds.), Wolfram Kistner. Justice and righteousness like a never-ending stream. Essays, reflectionss and discussion documents. Johannesburg: South African Council of Churches, 2008:122. 
Virtually all the nationalist slogans in the South African freedom struggle invoke the land and assert its primacy among the objectives of the struggle itself.

$\mathrm{Du}$ Preez ${ }^{38}$ reasons that for many white Afrikaans speaking people, just as for many black people, the almost irrational and primal feeling of owing a piece of land is an essential precondition for full citizenship.

Land restitution, land tenure and land redistribution processes should take these deeper dignifying meanings of land for many people into consideration, and seek the most effective and fruitful ways to address their needs to be reconciled with the original land, or at least to a more or less equivalent piece of land. In the light of the high percentage of failure where this direct redress had taken place, measures that ensure higher levels of success should accompany these practices of returning to a specific piece of land.

Wolfram Kistner ${ }^{39}$ makes a strong plea that churches also get involved in land reform practices. Even though churches do not own the major percentage of workable land, it will be of highly symbolic and motivational value if churches embark on such processes.

In a very illuminating way Kistner ${ }^{40}$ exposes the parallel between the subjugation of other human beings, as was the case during apartheid, and the subjugation of nature for the sake of progress. He therefore pleads that the quest for land restitution and land redistribution should also be accompanied by the quest for justice to nature.

Kistner ${ }^{41}$ employs the concept of healing to indicate what goal land restitution and land redistribution quests should strive to serve. This plea for healing co-incides with the idea that justice in the Christian tradition is restorative, reconciling and healing justice.

\section{Conclusion}

The inclusion of all people in the land as pathway to a life of inclusive dignity is suggested in this article as an indispensable ethical parameter for land reform processes in South Africa. This parameter prompts us to work with urgency on a broader level for the dawning of the day that all people have access to 'land', to a space and opportunities that facilitate a life of dignity. This parameter also prompts us to work for the dawning of the day when people will, with appropriate support, return to the original or equivalent piece of land as their specific pathway to a life of dignity.

38 M du Preez, A rumour of spring, p.160. An alumnus of the Faculty of Theology at Stellenbosch University, Old Testament scholar, Laiu Fachhai, offers a very helpful discussion of the central role that land plays in all covenants in the Old Testament. His discussion reveals the deeper meaning of land for people and also provides parameters for ethical decision-making on land questions. See L Fachhai, The land must be distributed equally. The promise and covenant aspects of land in the Old Testament. Delhi: Cambridge, 2009. W Kistner, The need for land-related justice in South Africa, p.125-126.

40 W Kistner, The need for land-related justice in South Africa, p.119.

41 W Kistner, The need for land-related justice in South Africa, p.127. 